\title{
STRUCTURAL FIBER INSULATING BOARD
}

\author{
(FOURTH EDITION)
}

\section{COMMERCIAL STANDARD CS42-49}

[Supersedes CS42-43]

Effective Date for New Production From November 15, 1949

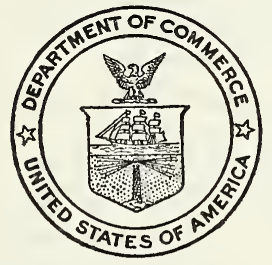

A RECORDED VOLUNTARY STANDARD

OF THE TRADE

UNITED STATES DEPARTMENT OF COMMERCE CHARLES SAWYER, Secretary 


\section{COMMODITY STANDARDS}

Simplified Practice Recommendations and Commercial Standards are developed by manufacturers, distributors, and users in cooperation with the Commodity Standards Division of the National Bureau of Standards. The purpose of Simplified Practice Recommendations is to eliminate avoidable waste through the establishment of standards of practice for stock sizes and varieties of specific commodities that currently are in general production and demand. The purpose of Commercial Standards is to establish standard methods of test, rating, certification, and labeling of commodities, and to provide uniform bases for fair competition.

The adoption and use of a Simplified Practice Recommendation or Commercial Standard is voluntary. However, when reference to a Commercial Standard is made in contracts, labels, invoices, or advertising literature, the provisions of the standard are enforceable through usual legal channels as a part of the sales contract.

A Simplified Practice Recommendation or Commercial Standard originates with the proponent industry. The sponsors may be manufacturers, distributors, or users of the specific product. One of these three elements of industry submits to the Commodity Standards Division the necessary data to be used as the basis for developing a standard of practice. The Division, by means of assembled conferences or letter referenda, or both, assists the sponsor group in arriving at a tentative standard of practice and thereafter refers it to the other elements of the same industry for approval or for constructive criticism that will be helpful in making any necessary adjustments. The regular procedure of the Division assures continuous servicing of each effective Simplified Practice Recommendation and Commercial Standard, through review and revision, whenever, in the opinion of the industry, changing conditions warrant such action. Simplified Practice Recommendations and Commercial Standards are printed and made available by the Department of Commerce through the Government Printing Office.

\section{COMMERCIAL STANDARD FOR STRUCTURAL FIBER INSULATING BOARD}

On May 16, 1932, at the instance of a group of fiber insulating board manufacturers, a joint conference representing all interests adopted a recommended standard for fiber insulating board. This standard was accepted by the industry, and issued by the National Bureau of Standards as Commercial Standard CS42-32. This standard was reaffirmed, with an amendment, in 1935.

A revision of the standard, designated CS42-43, became effective August 25, 1943. A recommended revision of CS $42-43$, submitted by the Insulation Board Institute, was circulated to the industry for written acceptance on April 26, 1949. Those concerned have since accepted and approved the revised standard as shown herein.

Project Manager: Andrew C. TAIT, Commodity Standards Division, National Bureau of Standards.

Technical Consultant: H. E. RoBInson, Building Technology Division, National Bureau of Standards. 
COMMERCIAL STANDARD CS42-49

for

\section{STRUCTURAL FIBER INSULATING BOARD}

\section{PURPOSE}

1.1 This standard is offered as a basis for common understanding in the insulating board industry. It establishes definite criteria of insulating board value and other physical requirements that should be possessed by this material, and presents a basis on which performance guarantees may be made by the manufacturer.

\section{SCOPE}

2.1 This standard is a minimum specification for six classes of structural fiber insulating board designated as follows:

Class A-Building board.

Class B-Lath (for plaster base).

Class C-Roof-insulation board.

Class D-Interior boards (factory finished):

D (1)-Interior-finish board.

D (2)-Panels (or tileboard).

D (3)-Plank.

Class E-Sheathing.

Class F-Interior boards (flame-resistant-finished surface):

F (1)-Interior-finish board.

F (2)-Panels (or tileboard).

F (3)-Plank.

2.2 The standard also covers physical requirements and tests for thermal conductivity, strength, water absorption, expansion, and finished surface flame resistance, and sets forth the standard commercial sizes, tolerances, and methods of packing and labeling.

\section{GENERAL REQUIREMENTS}

3.1 Composition.-Boards shall be manufactured principally from wood, cane, or other vegetable fiber, by a felting or molding process, suitable sizing material being incorporated in the product to render it water-resistant.

3.2 Construction.-The finished board may be either single- or multiple-ply. When multiple-ply boards $3 / 4$ inch or less in thickness are supplied, a suitable moisture-resistant cement shall be used to join the plies. Multiple-ply boards 1 inch and over in thickness shall be stapled, stitched, or thoroughly cemented, as specified. 


\section{DETAIL REQUIREMENTS}

4.1 Finishes.-Table 1 shows the surface and edge finishes for the six classes of structural fiber insulating board.

TABLE 1. Surface and edge finishes

\begin{tabular}{|c|c|c|c|}
\hline Class & Type of board & Surface finish & Edge finish \\
\hline A. & Building board & Natural ......... & Square. \\
\hline B.. & Lath for plaster base......... & -...do do & Short edges square or fabri- \\
\hline $\mathrm{C}_{-.-}$ & Roof-insulation board & ...... do & $\begin{array}{l}\text { cated; long edges fabricated. } \\
\text { Square, shiplapped, or offset. }\end{array}$ \\
\hline D $\ldots \ldots$ & Interior boards (factory fin- & & \\
\hline $\mathrm{D}(1)$ & Interior-finish board & $\begin{array}{l}\text { Factory surfaced, smooth } \\
\text { or textured. }\end{array}$ & \\
\hline $\begin{array}{l}\mathrm{D}(2) \\
\mathrm{D}(3)\end{array}$ & $\begin{array}{l}\text { Panels (or tileboard) } \\
\text { Plank }\end{array}$ & - & $\begin{array}{l}\text { Fabricated. } \\
\text { Long edges fabricated; short } \\
\text { edges square. }\end{array}$ \\
\hline $\mathrm{E}_{\ldots}$ & Sheathing & $\begin{array}{l}\text { Natural or factory surfaced, } \\
\text { or integrally treated. }\end{array}$ & $\begin{array}{l}\text { All edges square, or short edges } \\
\text { square and long edges fabri- } \\
\text { cated. }\end{array}$ \\
\hline$F(1)$ & & Factory surfaced, smooth or & Square. \\
\hline $\begin{array}{l}F(2) \\
F(3)--\end{array}$ & $\begin{array}{l}\text { Panels (or tileboard) } \\
\text { Plank }\end{array}$ & -...do do & $\begin{array}{l}\text { Fabricated. } \\
\text { Long edges fabricated; short } \\
\text { edges square. }\end{array}$ \\
\hline
\end{tabular}

4.2 Surfaces.-For plaster base, roof insulation, and similar applications, surfaces shall be free from cracks, lumps, excessive departure from planeness, or other defects. For interior finish, partitions, and similar applications where the board is exposed, surfaces shall be finished and shall be smooth and flat and reasonably free from coarse or hairy fibers. 
4.3 Physical properties.-Structural fiber insulating board shall have the limiting property values shown in table 2 , when tested according to methods herein described.

TABLE 2. Physical requirements of structural insulating board made from vegetable fibers

\begin{tabular}{|c|c|c|c|c|c|c|}
\hline \multirow{2}{*}{ Physical properties } & \multicolumn{6}{|c|}{ Class } \\
\hline & A & $\mathrm{B}$ & $\mathrm{C}$ & $\mathrm{D}$ & $\mathrm{E}$ & $\mathrm{F}$ \\
\hline $\begin{array}{l}\text { Thermal conductivity, max, Btu per hr per sq } \mathrm{ft} \text { per } \\
\text { deg } \mathrm{F} \text { per inch, at a mean temperature of } 75^{\circ} \mathrm{F} \ldots\end{array}$ & 0.38 & 0.38 & 0.38 & 0.38 & 0.40 & 0.38 \\
\hline $\begin{array}{l}\text { Transverse load without rupture, either direction, } \\
\text { min, pounds- } \\
\text { For: } 1 / 2 \text {-in. thickness } 3 / 4 \text {-in. thickness } \\
1 \text {-in. thickness } \\
11 / 2 \text {-in. thickness. } \\
2 \text {-in. thickness }\end{array}$ & $\begin{array}{c}12 \\
18 \\
24 \\
-\end{array}$ & $\begin{array}{c}12 \\
-24 \\
-\end{array}$ & $\begin{array}{c}7 \\
-14 \\
21 \\
28\end{array}$ & $\begin{array}{l}10 \\
15 \\
20 \\
---\end{array}$ & $\begin{array}{r}14 \\
\text { a } 21 \\
--\end{array}$ & $\begin{array}{r}10 \\
15 \\
20 \\
--\end{array}$ \\
\hline $\begin{array}{l}\text { Deflection at breaking load, min, inch- } \\
\text { For: } 1 / 2 \text {-in. thickness } \\
3 / 4 \text {-in. thickness } \\
1 \text {-in. thickness } \\
11 / 2 \text {-in. thickness. } \\
2 \text {-in. thickness }-\end{array}$ & $\begin{array}{r}0.25 \\
.19 \\
.12 \\
\end{array}$ & $\begin{array}{c}0.25 \\
.12 \\
-\end{array}$ & $\begin{array}{c}0.25 \\
.12 \\
.09 \\
.06\end{array}$ & $\begin{array}{r}0.15 \\
.11 \\
.07 \\
\end{array}$ & $\begin{array}{r}0.25 \\
\text { a. } 19 \\
.12 \\
\\
\end{array}$ & $\begin{array}{r}0.15 \\
.11 \\
.07 \\
. .-\end{array}$ \\
\hline $\begin{array}{l}\text { Deflection at specified minimum load, max, inches- } \\
\text { For: } 1 / 2 \text {-in. thickness } \\
3 / 2 \text {-in. thickness } \\
1 \text {-in. thickness } \\
11 / 2 \text {-in. thickness. } \\
2 \text {-in, thickness }\end{array}$ & $\begin{array}{r}0.85 \\
.65 \\
.42\end{array}$ & $\begin{array}{c}0.85 \\
.42\end{array}$ & $\begin{array}{c}1.25 \\
.62 \\
.46 \\
.31\end{array}$ & $\begin{array}{r}1.00 \\
.75 \\
.50\end{array}$ & $\begin{array}{r}0.75 \\
\text { a. } 56 \\
.37\end{array}$ & $\begin{array}{r}1.00 \\
.75 \\
.50 \\
-. \\
\end{array}$ \\
\hline Tensile strength parallel to surface, $\min , 1 \mathrm{~b}$ per sq in. b $_{-}$ & 150 & 150 & 100 & 150 & 150 & 150 \\
\hline $\begin{array}{l}\text { Tensile strength perpendicular to surface, } \min , \mathrm{lb} \\
\text { per sq ft-- }\end{array}$ & 600 & 600 & 500 & 600 & 600 & 600 \\
\hline Water absorption by volume, max, percent. & 7 & 7 & 10 & 10 & 10 & 10 \\
\hline Linear expansion, max, percent_........... & $1 / 2$ & $1 / 2$ & $1 / 2$ & $1 / 2$ & $1 / 2$ & $1 / 2$ \\
\hline lame-resistant-finished surface & & & & & & (c) \\
\hline
\end{tabular}

a These values applicable also to $25 / 32$-inch sheathing.

b Tensile strength requirements shall be applicable only on thicknesses up to and including 1 inch.

e $12 \mathrm{sq}$ in. of char. Flaming shall not continue more than 60 seconds after fuel is exhausted. 


\section{STANDARD SIZES AND TOLERANCES}

5.1 Standard commercial sizes. - The nominal width, length, and thickness dimensions shall be as specified in table 3 .

TaBle 3. Dimensions

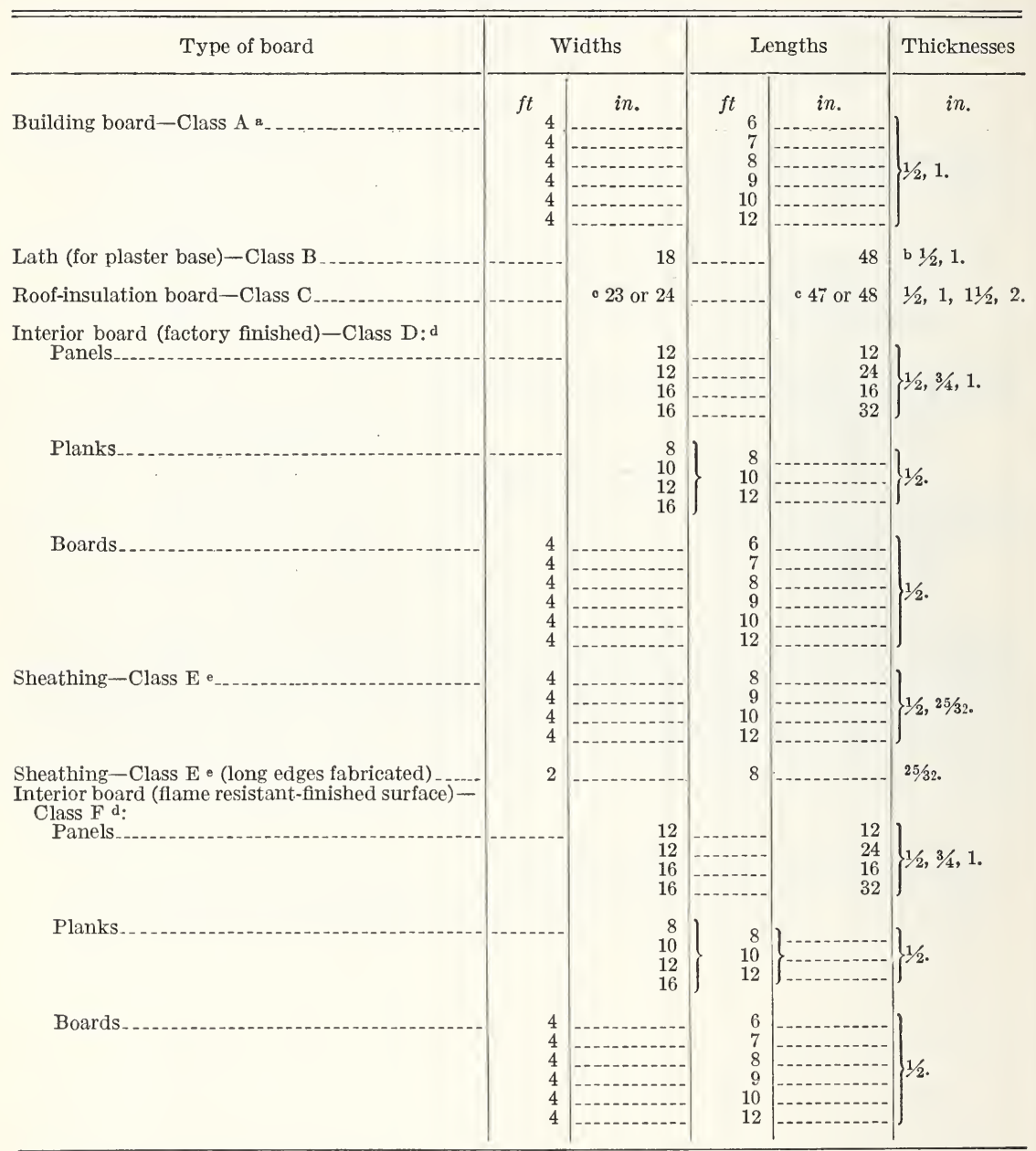

a Dimensions are over-all.

b For the $1 / 2$-in. thickness the dimensions are over-all; for the 1-in. thickness the dimensions may be either over-all or coverage.

c Either size, at the option of the manufacturer.

d Dimensions are coverage.

e Dimensions may be over-all or coverage.

\subsection{Tolerances.}

5.2.1 Length and width. - The tolerances for length and width of board shall be $+0,-1 / 16$ inch per foot, but the total tolerance shall not exceed $+0,-3 / 8$ inch per foot. 
5.2.2 Thickness. - The tolerances for thickness of board shall be:

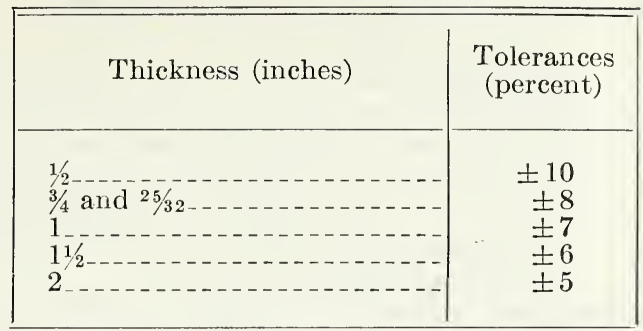

5.3 Rejection.-Any rejection shall be based upon failure to conform to the requirements of these specifications, and shall be reported to the seller within 10 working days from the receipt of the shipment by the purchaser. The notice of rejection shall contain a specific statement of the respects in which the boards have failed to conform to the requirements of these specifications.

\section{METHOD OF SAMPLING AND TESTING}

\subsection{Sampling.}

6.1.1 Selection of boards.-Boards shall be selected at random so as to give a fair representation of the entire shipment. The number of boards to be selected for test shall be as follows:

(a) LCL shipments: 0.5 percent of number of boards in shipment, but not less than three nor more than five boards of any shipment.

(b) Carload shipments: Five boards.

(c) More than one car or carrier load: Five boards from each car or carrier load.

6.1.2 Size of sample.-From each board a sample 36 by 48 inches shall be cut. When possible, the larger dimensions of the sample shall be crosswise of the longer dimension of the board as it is usually obtained. When the individual boards are less than 36 by 48 inches in size, enough material shall be taken to give the equivalent area.

6.2 Tests.

6.2.1 Test conditions.-All physical tests, except that for thermal conductivity, shall be made on specimens conditioned under prevailing atmospheric conditions, except in cases of dispute. These tests shall then be made on samples conditioned until equilibrium is obtained ${ }^{1}$ at a relative humidity of 48 to 52 percent and a temperature of $70^{\circ} \mathrm{F}$ to $75^{\circ} \mathrm{F}$.

6.2.2 Thermal conductivity shall be determined in accordance with the Standard Method of Test for Thermal Conductivity of Materials by Means of the Guarded Hot Plate (A. S. T. M. Designation: C17745). ${ }^{2}$

1 Normally, equilibrium should be obtained in 24 hours or less, with a moisture content not exceeding 10 percent by weight.

21946 Book of A. S. T. M. Standards, Part II. 
6.2.3 Transverse load.

6.2.3.1 Apparatus.-The apparatus shall consist of the following:

(a) Testing machine.-Any standard mechanical or hydraulic testing machine capable of applying and measuring the required load within an accuracy of plus or minus 2 percent may be used.

(b) Bearing edges. - The bearing edges shall be rounded to a radius of $3 / 8$ inch to prevent injury to the specimen. The bearing edges shall be straight and shall be selfalining so as to maintain full contact with the specimen throughout the test.

6.2.3.2 Test specimen. - The test specimen shall be 3 by 15 inches. Three specimens from the long dimension of each board and three at right angles thereto shall be tested.

6.2.3.3 Procedure.-The transverse load shall be determined by placing the specimen on horizontal bearing edges 12 inches apart and applying the load at midspan on a bearing parallel to the end supports, so that the head of the testing machine through which the load is applied moves at a rate of 12 inches, plus or minus 2 inches, per minute, until definite failure occurs.

6.2.3.4 Calculation and report.-The transverse load shall be recorded as the maximum load reached during the test. The average transverse load in each direction for sample shall be the average of three specimens taken from that direction. The total average transverse load in each direction shall be the average of all specimens in that direction for all samples.

6.2.4 Deflection tests.

6.2.4.1 Deflection at specified minimum load.-The deflection in inches shall be determined at the time each specimen is subjected to the minimum transverse load.

6.2.4.2 Deflection at breaking load.-The deflection in inches shall be determined at the time the breaking load is attained. The total average of the deflection shall be obtained for each direction of the samples.

6.2.5 Tensile strength parallel to surface.

6.2.5.1 Apparatus.-Any standard mechanical or hydraulic tensile testing machine may be used.

6.2.5.2 Test specimen.- Test specimens shall be prepared in accordance with figure 1. Three specimens from the long direction of each board and three at right angles thereto shall be tested.

6.2.5.3 Procedure.-Specimens shall be clamped in jaws at a minimum distance of 6 inches apart. The testing machine shall be set for a rate of separation of the jaws of 2 inches, $\pm 1 / 4$ inch, per minute. Specimens breaking within $1 / 2$ inch of the jaws shall be disregarded. Specimens after breaking shall be measured for width and thickness at the break to the nearest 0.01 inch.

6.2.5.4 Calculation and report. - The tensile strength in each direction for a sample shall be taken as the average, in pounds per square inch, of three specimens taken from that direction, based on the area of the specimen at the break. The total average value in each direction shall be the average of all samples in that direction. 


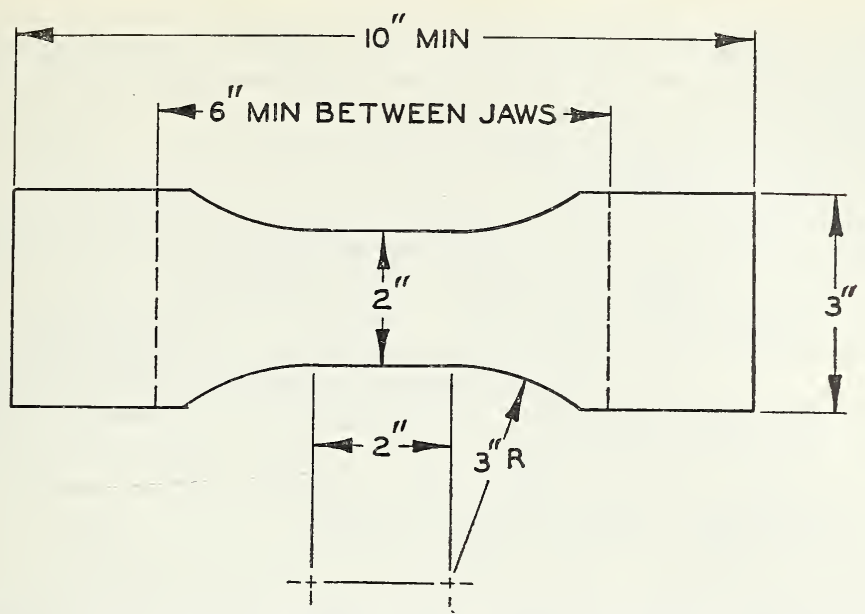

Figure 1. Specimen for determination of tensile strength parallel to surface.

6.2.6 Tensile strength perpendicular to surface.

6.2.6.1 Apparatus. - The apparatus shall be as shown in figure 2, and shall consist of two wooden blocks 6 by 6 by $1 \frac{1}{4}$ inches, supplied with hooks in the center as shown in figure 2. Any standard tension machine may be used for this test.

6.2.6.2 Test specimen.-The test specimen shall be 6 by 6 inches. Two specimens shall be tested.

6.2.6.3 Procedure.-The two surfaces of the specimens shall be glued to the wooden blocks with casein glue or other suitable adhesive. After the adhesive has set a sufficient length of time, a load shall be applied at the rate of 2 inches, $\pm 1 / 4$ inch, per minute at the hooks until separation occurs.

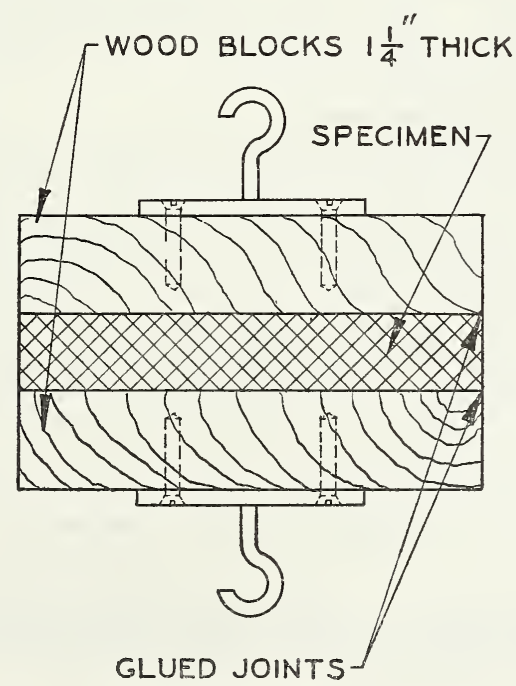

Figure 2. Apparatus for determination of tensile strength perpendicular to surface. $844327-50-2$ 
6.2.6.4 Calculation and report. The tensile strength perpendicular to the surface shall be reported as the average of the loads in pounds per square foot at the time of failure of the test specimens. The location of the line of failure shall be noted.

\subsubsection{Water absorption.}

6.2.7.1 Apparatus.-The apparatus shall consist of the following:

(a) Pan:-A pan or vessel not less than 15 by 15 inches, with a depth of at least 3 inches.

(b) Conditioning oven or room.-A conditioning oven or room that can be regulated to a temperature of $70^{\circ}$ to $75^{\circ} \mathrm{F}$ and a relative humidity of 48 to 52 percent.

(c) Thermometer.-An ordinary thermometer graduated in Fahrenheit degrees.

6.2.7.2 Test specimen.-The test specimen shall be 12 by 12 inches, with all four edges trimmed square.

6.2.7.3 Procedure.-The specimen shall be conditioned until equilibrium is obtained at a temperature of $70^{\circ}$ to $75^{\circ} \mathrm{F}$ and a relative humidity of 48 to 52 percent. The thickness of the specimen shall be measured and the volume calculated therefrom. Length, width, and thickness measurements should be made with reasonable accuracy. The specimen shall then be carefully weighed and submerged horizontally under 1 inch of distilled water maintained at a temperature of $70^{\circ}$ to $75^{\circ} \mathrm{F}$. After 2 hours of submersion, the specimen shall be placed on end to drain for 10 minutes, at the end of which time the excess surface water shall be removed by hand with a blotting paper or paper towel and the specimen immediately weighed.

6.2.7.4 Calculation and report.-The volume of water absorbed shall be calculated from the increase in weight of the specimen during the submersion and the water absorption shall be expressed as a percentage by volume based on the volume after conditioning.

6.2.8 Linear expansion.

6.2.8.1 Apparatus.-The apparatus shall consist of the following:

(a) Glass-marking pencil or a wax crayon.

(b) Razor blade.

(c) Magnifying lens.

(d) Steel scale (a 12 -inch steel scale reading to 0.01 inch).

(e) Conditioning oven or room that can be maintained at a temperature of $70^{\circ}$ to $75^{\circ} \mathrm{F}$ and a relative humidity of 48 to 52 percent, and of 90 to 95 percent.

6.2.8.2 Test specimen.-The test specimen shall be 3 by 12 inches. Two specimens shall be provided, one cut parallel with the long dimension of each board and one from the same board cut at right angles to the long dimension. When a board does not permit obtaining a 12-inch specimen, the maximum length possible shall be used but it shall be at least 6 inches.

6.2.8.3 Procedure.-At each of two points approximately 10 inches apart on the center line of each specimen, a small area shall be coated by rubbing with the glass-marking pencil (or wax crayon). When smaller specimens are used, the distance between marks shall be the maximum possible. A fine cross shall be made with the razor blade on the center line in each of these two areas as reference points 
for length measurements. The specimens shall then be conditioned until equilibrium is obtained at 48 to 52 percent relative humidity and a temperature of $70^{\circ}$ to $75^{\circ} \mathrm{F}$, and measurements shall be made of the distance between the two reference points. By means of the scale and magnifying lens, readings shall be made to the nearest 0.005 inch. The specimens shall next be conditioned until equilibrium is obtained at 90 to 95 percent relative humidity and a temperature of $70^{\circ}$ to $75^{\circ} \mathrm{F}$, after which the distance between the two reference points shall be again measured. The measurements shall be made in the conditioned air specified in each case, or as quickly as possible after the specimen is removed therefrom.

6.2.8.4 Calculation and report.-The linear expansion shall be reported as the percentage increase in length between the reference marks, based on the length at 50 percent relative humidity.

6.2.9 Flame-resistant-finished surface (inclined panel test). ${ }^{3}$

6.2.9.1 Apparatus.-The specimen under test shall be supported so that it is at an angle of $45^{\circ}$, with the horizontal two edges of such plane being horizontal. This may be accomplished by resting the specimen on four points; but it is necessary, whatever method of support be employed, that (a) the central portion of the specimen shall not be shielded from the flame, (b) the supports shall not prevent access of air for combustion, (c) the apparatus shall be such that the progress of the test can be observed.

A flat-bottomed cup of $5 / 3$-inch internal diameter and $9 / 32$-inch depth shall be placed on a support composed of material of low thermal conductivity. The cup shall be made of sheet iron about $1 \frac{1}{32}$ inch thick. It shall be supported so that the center of its base is 1 inch vertically below a point on the lower surface of the test specimen, 3 inches from its lower horizontal edge, and midway between the inclined edges. See figure 3.

6.2.9.2 Test specimen.-Three 12- by 12-inch specimens of the insulating board shall be tested.

6.2.9.3 Procedure.-Each specimen shall be conditioned until equilibrium is obtained at a temperature of $70^{\circ}$ to $75^{\circ} \mathrm{F}$ and a relative humidity of 48 to 52 percent. (See footnote 1, page 5.) The specimen is placed on the test apparatus and $1 \mathrm{cc}$ of absolute ethyl alcohol is placed in the cup from a suitable pipette or other means, and ignited (with the test specimen in place) by a small gas or oil jet or other suitable small source of heat, which shall be removed as soon as the alcohol is lighted. The test shall be made in a draft-free room or enclosure in a subdued light. One minute after the fuel has been exhausted, any flame and glow on the specimen shall be extinguished, and those facts reported and the area of char determined. If the duration of flaming is less than 1 minute any smoldering shall be extinguished and the area of char measured. ${ }^{4}$

6.2.9.4 Calculation and report.- The area of char and the duration of flaming shall be reported. The average of the three specimens shall be taken as the test results.

\footnotetext{
3 This test designed for production evaluation.

4 Area of char shall be that portion which shows definite decomposition or shrinkage, and is black to dark brown in color. Areas smoked or discolored only shall not be included in area of char.
} 

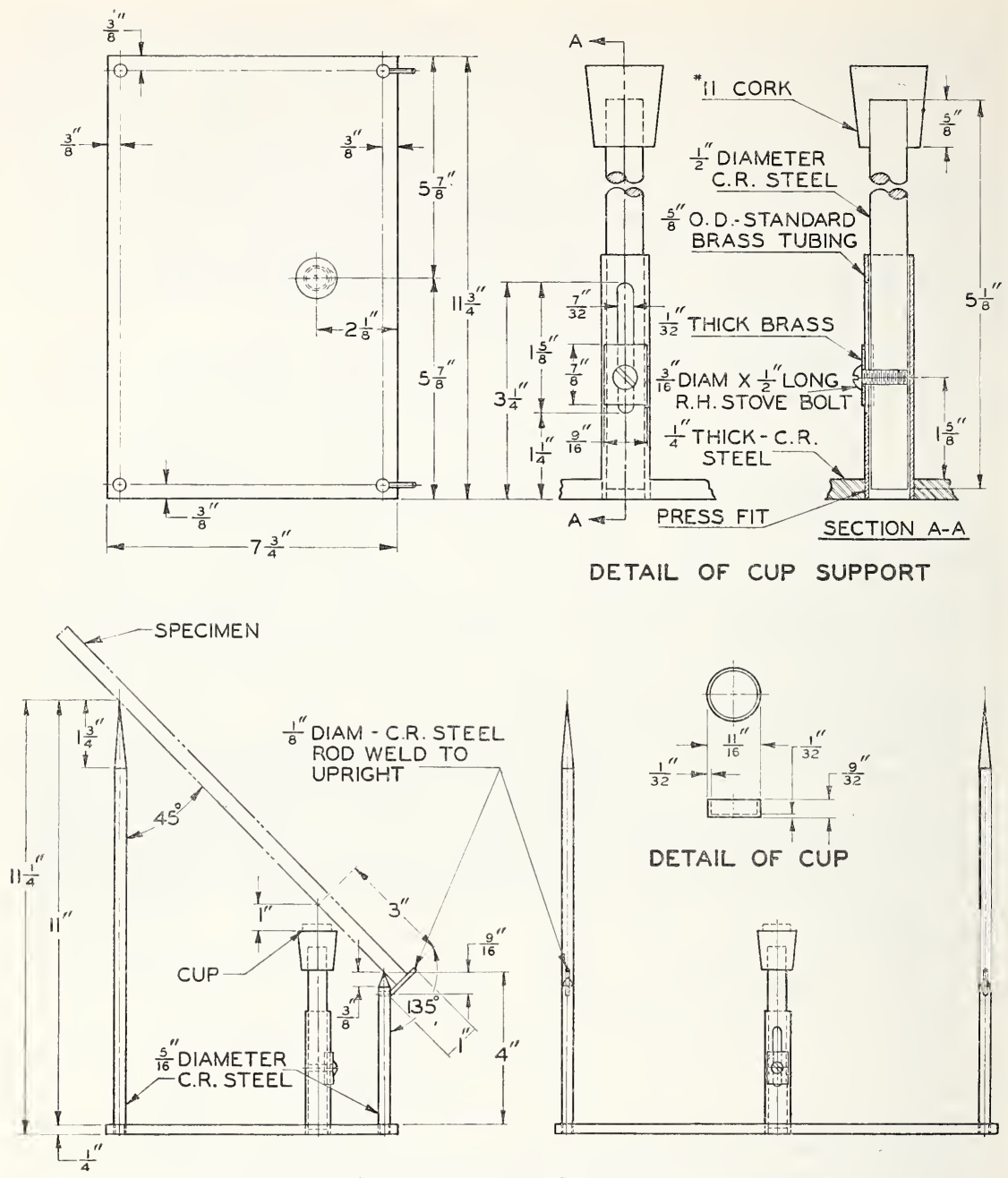

Figure 3. Apparatus for making flame-spread test.

\section{PACKING AND LABELING}

7.1 Packing.-Unless otherwise specified, the structural fiber insulating board shall be delivered in packages so constructed as to insure acceptance by common or other carriers for safe transportation, at the lowest rate, to the point of delivery.

7.2 Marking. - When specified, the shipping containers shall be marked with the name of the material, class, size, and quantity contained therein, as defined by the contract or order under which shipment is made, the name of the contractor, and the number of the contract or order.

7.3 Labeling.-In order to assure the purchaser that he is getting structural fiber insulating board conforming to this commercial standard it is recommended that producers, either individually or in concert 
with their trade association or testing laboratories, issue a guarantee label containing the following wording:

This structural fiber insulating board is guaranteed by

_..._. to meet all requirements of Commercial

Standard CS42-49, as developed by the industry under the procedure of the National Bureau of Standards, and issued by the United States Department of Commerce.

7.4 Purchasers should specify the class, purpose for which used, dimensions, and kind of surface desired; also whether cemented, stapled, or stitched joining of plies is desired in boards 1 inch in thickness and over. Under Class $C$ (roof-insulation board), when other than square-edge finish is desired, the kind desired should be specified. (See table 1.)

\section{EFFECTIVE DATE}

8.1 Having been passed through the regular procedure of the Commodity Standards Division, and approved by the acceptors hereinafter listed, this commercial standard was issued by the United States Department of Commerce, effective from November 15, 1949.

\section{Edwin W. Ely, \\ Chief, Commodity Standards Division.}

\section{HISTORY OF PROJECT}

9.1 Pursuant to a request from manufacturers of fiber insulating board, a general conference of manufacturers, distributors, and users was held in Chicago, Ill., on May 16, 1932, at which time a recommended standard for structural fiber insulating board was approved for circulation to the trade for acceptance. Following written acceptance from a satisfactory majority, the standard was promulgated as CS42-32, to become effective for new production on September 15, 1932 .

9.2 First revision.-At the request of a manufacturer of laminated insulation board, the standing committee considered the standard for revision late in 1934 with special reference to the temperature of drying preparatory to determining thermal conductivity. While the committee believed that there was no need for general revision of the standard, it approved, as an amendment, a reduction of the drying temperature from $220^{\circ}$ to $160^{\circ} \mathrm{F}$ for those types of boards which are injured by the higher temperature. The recommendation of the standing committee was circulated to the industry on June 24,1935 , and, in the absence of opposition, it was incorporated in the second edition of this standard, designated CS42-35.

9.3 Second revision.-On February 24, 1943, the Insulation Board Institute submitted a proposed revision which included requirements for five classes of structural fiber insulating board, as compared with two classes covered in the previous edition. Upon approval by the standing committee, the recommended revision was submitted on April 12, 1943 to the trade for written acceptance. Following acceptance by a satisfactory majority, the establishment of the revision was announced July 24, 1943 as Commercial Standard CS42-43. 
9.4 Third revision.-On January 20, 1948, the Insulation Board Institute submitted a proposed revision, which consisted of the addition of requirements and tests for Class $\mathrm{F}$, interior boards (flame-retardant surface), and certain other changes, including physical requirements for tensile strength perpendicular to surface, together with illustrations. Upon approval by the standing committee, the recommended revision was submitted on April 26, 1949, to the industry and trade for written acceptance.

Many signed acceptances were received as well as some helpful suggestions for improving and strengthening the standard. On September 12, 1949, authors of these suggestions and others interested met with representatives of the standing committee and the Commodity Standards Division at the National Bureau of Standards. On that occasion desirable modifications were made, including a change in designation for Class F, from "Interior boards (flame-retardant surface)," to "Interior boards (flame-resistant-finished surface)." This action was made known to all concerned, and in view of the fact that sufficient acceptances of a representative character had been received, the standard was approved for promulgation, effective from November 15, 1949.

\section{STANDING COMMITTEE}

10.1 The following individuals comprise the membership of the standing committee, which is to review, prior to circulation for acceptance, revisions proposed to keep the standard abreast of progress. Comment concerning the standard and suggestions for revision may be addressed to any member of the committee or to the Commodity Standards Division, National Bureau of Standards, which acts as secretary for the committee.

Frank B. Rowley, University of Minnesota, Minneapolis 14, Minn. (Chairman). J AMES V. Jones, Armstrong Cork Co., Lancaster, Pa.

G. M. Syverson, Masonite Corp., 111 West Washington St., Chicago 2, Ill.

I. L. Birner, The Celotex Corp., 120 South TaSalle St., Chicago 3, Ill.

A. S. Bull, Insulite Division, Minnesota \& Ontario Paper Co., 500 Baker Arcade Building, Minneapolis 2, Minn.

David B. Anderson, Wood Conversion Co., First National Bank Building, St. Paul 1, Minn.

James H. Conover, U. S. Gypsum Co., 1253 West Diversey Parkway, Chicago 14 , Ill.

H. R. Northup, National Retail Lumber Dealers Association, 1713 Rhode Island Avenue NW., Washington, D. C.

S. P. Thompson, 807 15th Street NW., Washington, D. C. (representing National Retail Lumber Dealers Association).

Theodore I. Coe, American Institute of Architects, 1741 New York Avenue NW., Washington 6, D. C.

R. S. 'Dill, Building Technology Division, National Bureau of Standards, Washington 25 , D. C.

J. C. PeEBLEs, Illinois Institute of Technology, 3300 Federal St., Chicago 16, Ill.

James McCawley, United Poofing Contractors Association, 431 South Dearborn St., Chicago 5, Ill. 


\section{ACCEPTANCE OF COMMERCIAL STANDARD}

If acceptance has not previously been filed, this sheet properly filled in, signed, and returned will provide for the recording of your organization as an acceptor of this commercial standard.

\section{Date}

Commodity Standards Division, National Bureau of Standards, Washington 25, D. C.

\section{Gentlemen:}

We believe that the Commercial Standard CS42-49 constitutes a useful standard of practice, and we individually plan to utilize it as far as practicable in the

production $^{1} \quad$ distribution $^{1} \quad$ purchase $^{1} \quad$ testing $^{1}$

of structural fiber insulating board. We reserve the right to depart from it as we deem advisable.

We understand, of course, that only those articles which actually comply with the standard in all respects can be identified or labeled as conforming thereto.

Signature of authorized officer

(In ink)

(Kindly typewrite or print the following lines)

Name and title of above officer

Organization

(Fill in exactly as it should be listed)

Street address

City, zone, and State 1 Underscore which one. Please see that separate acceptances are filed for all subsidiary companies and
affiliates which should be listed separately as acceptors. In the case of related interests, trade associations,
trade papers, etc., desiring to record their general support, the words "General Support" should be added
after the signature. 


\section{TO THE ACCEPTOR}

The following statements answer the usual questions arising in connection with the acceptance and its significance:

1. Enforcement.-Commercial standards are commodity specifications voluntarily established by mutual consent of those concerned. They present a common basis of understanding between the producer, distributor, and consumer and should not be confused with any plan of governmental regulation or control. The United States Department of Commerce has no regulatory power in the enforcement of their provisions, but since they represent the will of the interested groups as a whole, their provisions through usage soon became established as trade customs, and are made effective through incorporation into sales contracts by means of labels, invoices, and the like.

2. The acceptor's responsibility. - The purpose of commercial standards is to establish for specific commodities, nationally recognized grades or consumer criteria, and the benefits therefrom will be measurable in direct proportion to their general recognition and actual use. Instances will occur when it may be necessary to deviate from the standard and the signing of an acceptance does not preclude such departures; however, such signature indicates an intention to follow the commercial standard where practicable, in the production, distribution, or consumption of the article in question.

3. The Depariment's responsibility.-The major function performed by the Department of Commerce in the voluntary establishment of commercial standards on a Nation-wide basis is fourfold: first, to act as an unbiased coordinator to bring all interested parties together for the mutually satisfactory adjustment of trade standards; second, to supply such assistance and advice as past experience with similar programs may suggest; third, to canvass and record the extent of acceptance and adherence to the standard on the part of producers, distributors, and users; and fourth, after acceptance, to publish and promulgate the standard for the information and guidance of buyers and sellers of the commodity.

4. Announcement and promulgation.-When the standard has been endorsed by a satisfactory majority of production or consumption in the absence of active, valid opposition, the success of the project is announced. If, however, in the opinion of the standing committee or the Department of Commerce, the support of any standard is inadequate, the right is reserved to withhold promulgation and publication. 


\section{ACCEPTORS}

The organizations listed below have individually accepted this standard for use as far as practicable in the production, distribution, testing, or purchase of structural fiber insulating board. In accepting the standard, they reserved the right to depart therefrom as they individually deem advisable. It is expected that articles that actually comply with the requirements of this standard in all respects will be regularly identified or labeled as conforming thereto, and that purchasers will require such specific evidence of conformity.

\section{ASSOCIATIONS \\ (General Support)}

American Institute of Architects, Spokane Chapter, Spokane, Wash.

American Specification Institute, Chicago, Ill.

Carolina Lumber \& Building Supply Association, Inc., Charlotte, N. C.

Greater New York Lumber Industries, Inc., New York, N. Y.

Insulation Board Institute, Chicago, Ill.

Michigan Retail Lumber Dealers Association, Lansing, Mich

National Roofing Contractors Association, Chicago, Ill.

Southern California Retail Lumber Association, Los Angeles, Calif.

\section{FIRMS AND OTHER INTERESTS}

Adams, Franklin O., Tampa, Fla.

Anderson Lumber Co., Ogden, Utah.

Andrews, Jones, Biscoe \& Goodell, Boston, Mass. Armour Research Foundation, Chicago, Ill.

Armstrong Cork $\mathrm{Co}$, Lancaster, $\mathrm{Pa}$.

Baxter, C. B., \& Co., Kansas City, Mo.

Berger \& Kelley, Champaign, Ill.

Bird \& Son, Inc., East Walpole, Mass.

Blaw-Knox Co., Blawnox, Pa.

Botsford Lumber Co., Winona, Minn.

Bovard, William R., Kansas City, Mo. (General support.)

Bowser-Morner Testing Laboratories, Dayton, Ohio

Brazer, Clarence W., New York, N. Y.

Brust \& Brust, Milwaukee, Wis.

Bucky, Fred W., Jr., Jacksonville, Fla.

Cameron, Wm.,'\& Ço., Waco, Tex.

Cameron Lumber Co., Inc., Newburgh, N. Y.

Cannon \& Mullen, Salt Lake City, Utah.

Carstens Brothers, Ackley, Iowa.

Celotex Corp., The, Chicago, Ill.

Central of Georgia Railway Co., Savannah, Ga.

Charlottesville Lumber Co., Inc., Charlottesville, Va.

Coe Manufacturing Co., New York, N. Y. (General support.)

Conrad \& Cummings, Binghamton, N. Y.

Conwell, E. L., \& Co., Philadelphia, $\mathrm{Pa}$

Cram \& Ferguson, Boston, Mass.

Crowell \& Lancaster, Bangor, Maine.

Curtis Cos., Inc., Clinton, Iowa, and other cities.

Dearstine, J. C., Lumber Co., Schenectady, N. Y.

DeJarnette, Charles W., Des Moines, Iowa. (General support.)

Detroit, City of, City Engineer's Office, Detroit, Mich.

Detroit Edison Co., Detroit, Mich.

Detroit Testing Laboratory, Detroit, Mich.

Dickerson Lumber Co., Huntington, W. Va.

Dix Lumber Co., Cambridge, Mass.

Everett, H. F., \& Associates, Allentown, $\mathrm{Pa}$.

Fir-Tex Insulating Board Co., Portland, Oreg., and St. Helens, Oreg.

Flintkote Co., The, New York, N. Y.

Florida, University of, Gainesville, Fla.

Fort Wayne Builders' Supply Co., Fort Wayne, Ind.

General Millwork Corp., Utica, N. Y.

Gloekler Refrigerator Co., Erie, Pa.

Haralson \& Mott, Fort Smith, Ark.

Hawkins Lumber \& Warehouse Co., Boston, Mass.
Herron, James H., Co., The, Cleveland, Ohio.

Hoffman Lumber Co., Pittsburgh, Pa., and West Chester, $\mathrm{Pa}$.

Holden, McLaughlin \& Associates, New York, N.Y. Hope, Frank L., San Diego, Calif.

Jergens, Andrew, Co., The, Cincinnati, Ohio. Johns Manville Sales Corp., New York, N. Y.

Kansas State College, Department of Architecture, Manhattan, Kans.

Keich \& O'Brien, Warren, Ohio.

Latenser, John, \& Sons, Omah?, Nebr.

Law, Law, Potter \& Nystrom, Madison, Wis.

Levy, Will, St. Louis, Mo.

Loeb, Laurence M., White Plains, N. Y.

Los Angeles, City of, Los Angeles, Calif.

Lyman-Hawkins Lumber Co., A kron, Ohio.

Maisewood Insulation Co., Dubuque, Iowa.

Mann \& Co., Hutchinson, Kans.

Markland, M. B., Contracting Co., Atlantic City, N. J.

Marr, Office of Charles J., New Philadelphia, Ohio.

Marshall-Wright Lumber Co., Ionia, Mich.

Mason Lumber Co., Jacksonville, Fla.

Masonite Corp., Chicago. Hll. (General support.)

Massena \& duPont, Wilmington, Del.

Metropolitan Millwork Co., Brooklyn, N. Y.

Michigan State College, College of Engineering, East Lansing, Mich.

Michigan Wholesalers, Inc., Jackson, Mich.

Midwest Lumber Co., Dubuque, Iowa.

Milier \& Vrydagh, Terre Haute, Ind.

Minnesota \& Ontario Paper Co., Insulite Division, Minneapolis, Minn.

Minnesota, University of, Engineering Experiment Station, Minneapolis, Minn.

Moore Dry Dock Co., Oakland, Calif.

Muhlenberg Bros., Reading, Pa.

National Gypsum Co., Buffalo, N. Y.

National Refrigerators Co., St. Louis, Mo.

O \& N Lumber Co., Menomonie, Wis.

Odend'hal, E. A., \& Co., Norfolk, Va.

Officer, Gwynn, Lafayette, Calif.

Patzig Testing Laboratories, Des Moines, Iowa.

Pehrson, G. A., \& Associates, Spokane, Wash.

Phelps, Dewees \& Simmons, San Antonio, Tex.

Pittsburgh Testing Laboratory, Pittsburgh, Pa.

Plastergon Wall Board Co., The, Buffalo, N. Y.

Portsmouth Lumber Corp., Portsmouth, Va.

Resnikoff, Abraham, New York, N. Y.

Rock Hill Lumber Co., Rock Hill, S. C.

Rolfe Building Material Co., New Brunswick, N. J.

Schaeffer, Hooton \& Wilson, Bloomington, Ill.

Scott Testers, Inc., Providence, R. I. (General support.)

Sears, Roebuck \& Co., Chicago, Ill.

Simpson Logging Co., Seattle, Wash

Smither, Henry C., Koofing Co., Indianapolis, Ind.

Standard Lumber Co., Spokane, Wash.

Staub \& Rather, Houston, Tex.

Stevens, John Howard \& John Calvin, Portland, Maine.

Stewart, A. P., Lumber Co., Thermopolis, Wyo.

Suwannee Wood Preservers, Inc., Live Oak, Fla.

Sweet's Catalog Service, New York, N. Y. (General support.)

Taylor, Ellis Wing, Los Angeles, Calif.

Temple, Seth V., and Arthur, Davenport, Iowa.

Texas Technological College, Department of Architecture, Lubbock, Tex. (General support.)

Thal, Nelson E., Toledo, Ohio.

Thorne, Henry Calder, Ithaca, N. Y.

United States Testing Co., Inc., Hoboken, N. J. 
Velde Lumber Co., Pekin, Ill.
Virginia Polytechnic Institute, Department of Architectural Engineering, Blacksburg, Va. (General support.)

Wabash Railroad Co., St. Louis, Mo.

Washington, State College of, Pullman, Wash.

Welch, Carroll E., Huntington, N. Y.

Wenthe Bros. Co., Effingham, Ill.

West Lumber Co., Atlanta, Ga.

Wight \& Wight, Kansas City, Mo.

Willatsen, Andrew, Seattle, Wash.

Wood Conversion Co., St. Paul, Minn.

\section{UNITED STATES GOVERNMENT}

Agriculture, U. S. Department of, Division of Purchase, Sales \& Traffic, Washington, D. C.

Air Materiel Command, Wright-Patterson Air Force Base, Dayton, Ohio.

Technical Committee on Heat Insulating Materials, Federal Specifications Board, Washington, D. C.

\section{COMMERCIAL STANDARDS}

CS No.

Item

0-40. Commercial standards and their value to business (third edition).

1-42. Clinical thermometers (third edition).

2-30. Mopsticks.

3-40. Stoddard solvent (third edition).

4-29. Staple porcelain (all-clay) plumbing fixtures.

5-46. Pipe nipples, brass, copper, steel, and wrought iron (second edition).

6-31. Wrought-iron pipe nipples (second edition). Superseded by CS5-46.

7-29. Standard weight malleable iron or steel screwed unions.

8-41. Gage blanks (third edition).

9-33. Builders' template hardware (second edition).

10-29. Brass pipe nipples. Superseded by CS5-46.

11-41. Moisture regains of cotton yarns (second edition).

12-48. Fuel oils (sixth edition).

13-44. Dress patterns (fourth edition).

14-43. Boys' button-on waists, shirts, junior and sport shirts (made from woven fabrics) (third edition).

15-46. Men's pajama sizes (made from woven fabrics) (third edition).

16-29. Wall paper.

17-47. Diamond core drill fittings (fourth edition).

18-29. Hickory golf shafts.

19-32. Foundry patterns of wood (second edition).

20-47. Staple vitreous china plumbing fixtures (fourth edition).

21-39. Interchangeable ground-glass joints, stopcocks, and stoppers (fourth edition).

22-40. Builders' hardware (nontemplate) (second edition).

23-30. Feldspar.

24-43. Screw threads and tap-drill sizes.

25-30. Special screw threads. Superseded by CS24-43.

26-30. Aromatic red cedar closet lining.

27-36. Mirrors (second edition).

28-46. Cotton fabric tents, tarpaulins and covers (second edition).

20-31. Staple seats for water-closet bowls.

30-31. Colors for sanitary ware. (Withdrawn as commercial standard, March 15, 1948.

31-38. Wood shingles (fourth edition).

$32-31$. Cotton cloth for rubber and pyroxylin coating.

33-43. Knit underwear (exclusive of rayon) (second edition).

34-31. Bag, case, and strap leather.

35-47. Hardwood plywood (third edition).

36-33. Fourdrinier wire cloth (second edition).

37-31. Steel bone plates and screws.

38-32. Hospital rubber sheeting.

39-37. Wool and part wool blankets (second edition). (Withdrawn as commercial standard, July 14, 1941.)

40-32. Surgeons' rubber gloves.

41-32. Surgeons' latex gloves.

42-49. Structural fiber insulating board (fourth edition).

43-32. Grading of sulphonated oils.

44-32. Apple wraps.

45-48. Douglas fir plywood (eighth edition)

46-49. Hosiery lengths and sizes (fourth edition).

47-34. Marking of gold-filled and rolled-gold-plate articles other than watchcases.

48-40. Domestic burners for Pennsylvania anthracite (underfeed type) (second edition).
CS No.

Item

49-34. Chip board, laminated chip board, and miscellaneous boards for bookbinding purposes.

50-34. Binder's board for bookbinding and other purposes.

51-35. Marking articles made of silver in combination with gold.

52-35. Mohair pile fabrics (100-percent mohair plain velvet, 100-percent mohair plain frieze, and 50-percent mohair plain frieze).

53-35. Colors and finishes for cast stone.

54-35. Mattresses for hospitals.

55-35. Mattresses for institutions.

56-49. Oak flooring (third edition).

57-40. Book cloths, buckrams, and impregnated fabrics for bookbinding purposes except library bindings (second edition).

58-36. Woven elastic fabrics for use in overalls (overall elastic webbing)

59-44. Textiles-testing and reporting (fourth edition).

60-48. Hardwood dimension lumber (second edition).

61-37. Wood-slat venetian blinds.

62-38. Colors for kitchen accessories.

63-38. Colors for bathroom accessories.

64-37. Walnut veneers.

65-43. Methods of analysis and of reporting fiber composition of textile products (second edition).

66-38. Marking of articles made wholly or in part of platinum.

67-38. Marking articles made of karat gold.

68-38. Liquid hypochlorite disinfectant, deodorant, and germicide.

69-38. Pine oil disinfectant.

70-41. Phenolic disinfectant (emulsifying type) (second edition) (published with CS71-41).

71-41. Phenolic disinfectant (soluble type) (second edition) (published with CS70-41).

72-38. Household insecticide (liquid spray type).

73-48. Old growth Douglas fir, Sitka spruce, and Western hemlock standard stock doors (fourth edition).

74-39. Solid hardwood wall paneling.

75-42. Automatic mechanical draft oil burners de signed for domestic installations (second edition).

76-39. Hardwood interior trim and molding.

77-48. Enameled cast-iron plumbing fixtures (second edition)

78-40. Ground-and-polished lenses for sun glasses (second edition) (published with CS79-40).

79-40. Blown, drawn, and dropped lenses for sun glasses (second edition) (publisshed with CS78-40)

80-41. Electric direction signal systems other than semaphore type for commercial and other vehicles subject to special motor vehicle laws (after market).

81-41. Adverse-weather lamps for vehicles (after market).

82-41. Inner-controlled spotlamps for vehicles (after market).

83-41. Clearance, marker, and identification lamps for vehicles (after market).

84-41. Electric tail lamps for vehicles (after market).

85-41. Electric license-plate lamps for vehicles (after market).

86-41. Electric stop lamps for vehicles (after market). 
CS No.

Item

87-41. Red electric warning lanterns.

88-41. Liquid burning flares.

89-40. Hardwood stair treads and risers.

90-49. Power cranes and shovels.

91-41. Factory-fitted Douglas fir entrance doors.

92-41. Cedar, cypress, and redwood tank stock lumber.

93-41. Portable electric drills (exclusive of high frequency).

94-41. Calking lead.

95-41. Lead pipe.

96-41. Lead traps and bends.

97-42. Electric supplementary driving and passing lamps for vehicles (after market).

98-42. Artists' oil paints.

99-42. Gas floor furnaces-gravity circulating type.

100-47. Porcelain-enameled steel utensils (third edition).

101-43. Flue-connected oil-burning space heaters equipped with vaporizing pot-type burn. ers.

102- (Reserved for Diesel and fuel-oil engines.)

103-48. Rayon jacquard velour (with or without other decorative yarn) (second edition).

104-49. Warm-air furnaces equipped with vaporizing type oil burners (third edition).

105-48. Mineral wool insulation for low temperatures (second edition).

106-44. Boys' pajama sizes (woven fabries) (second edition).

107-45. Commercial electric-refrigeration condensing units (second edition). (Withdrawn as commercial standard September 4, 1947).

108-43. Treading automobile and truck tires.

109-44. Solid-fuel-burning forced-air furnaces.

110-43. Tire repairs-vulcanized (passenger, truck, and bus tires)

111-43. Earthenware (vitreous-glazed) plumbing fixtures.

112-43. Homogeneous fiber wallboard.

113-44. Oil-burning floor furnaces equipped with vaporizing pot-type burners.

114-43. Hospital sheeting for mattress protection.

115-44. Porcelain-enameled tanks for domestic use.

116-44. Bituminized-fiber drain and sewer pipe.

117-49. Mineral wool insulation for heated industrial equipment (second edition).

118-44. Marking of jewelry and novelties of silver.

(E) 119-45.1 Dial indicators (for linear measurements).

120-48. Standard stock ponderosa pine doors (third edition).

121-45. Women's slip sizes (woven fabries).

122-45. Western hemlock plywood.

123-49. Grading of diamond powder (second cdition).

(E) 124-45.1 Master disks.

125-47. Prefabricated homes (second edition).
Item

CS No.

126-45. Tank mounted air compressors. drinking water coolers.
drinting

128-45. Men's sport shirt sizes-woven fabrics (other than those marked with regular neckband sizes).

129-47. Materials for safety wearing apparel (second edition).

130-46. Color materials for art education in schools.

131-46. Industrial mineral wool products, all typestesting and reporting.

132-46. Hardware cloth

133-46. Woven wire netting.

134-46. Cast aluminum cooking utensils (meta] composition).

i35-46. Men's shirt sizes (exclusive of work shirts).

136-46. Blankets for hospitals (wool, and wool and cotton).

137-46. Size measurements for men's and boys' shorts (woven fabries).

138-47. Insect wire screening.

139-47. Work gloves.

140-47. Testing and rating convectors.

141-47. Sine bars, blocks, plates, and fixtures.

142-47. Automotive lifts.

143-47. Standard strength and extra strength perforated clay pipe.

144-47. Formed metal porcelain enameled sanitary ware.

145-47. Testing and rating hand-fired hot-watersupply boilers.

146-47. Gowns for hospital patients.

147-47. Colors for molded urea plastics.

148-48. Men's circular flat and rib knit rayon underwear.

149-48. Utility type house dress sizes.

150-48. Hot-rolled rail steel bars (produced from T-section rails)

151-48. Body measurements for the sizing of apparel for infants, babies, toddlers, and children (for the knit underwear industry).

152-48. Copper naphthenate wood-preservative.

153-48. Body measurements for the sizing of apparel for girls (for the knit underwear industry). 154- (Reserved for wire rope).

155-49. Body measurements for the sizing of apparel for boys (for the knit underwear industry). 156-49. Colors for polystyrene plastics.

157-49. Ponderosa pine and sugar pine plywo d.

58-49. Model forms for girls' apparel.

159-49. Sun-glass lenses made of ground and polished plate glass, thereafter thermally curved.

160-49. Wood-fiber blanket insulation (for building construction).

161-49. "Standard Grade" hot-dipped galvanized ware.

162-49. Tufted bedspreads.

1 Where "(E)" precedes the CS number, it indicates an emergency commercial standard, drafted under war conditions with a view toward early revision.

Notice.-Those interested in commercial standards with a view toward accepting them as a basis of everyday practice may secure copies of the above standards, while the supply lasts, by addressing the Commodity Standards Division, National Bureau of Standards, Washington 25, D. C. 
